\title{
Breakthrough the Legal Principle of the Civic Court Procedure
}

\author{
Fence M Wantu \\ University of Gorontalo State
}

\begin{abstract}
The principle of law in civil law has general characteristic, meaning that it applies in any situation, not only apply or purpose for certain event. Some legal principles in civic law are in need for attention: point d'interet point d'action principle; court principle with simple, fast, and cheap way; passive judge principle; judge and assembly principle; transparency of court for public; equality principle; court principle for justice based on The Divine of the Only God; and principle of judge decision with reasons.
\end{abstract}

Keywords: Legal Principles, Procedure of Law, Reformation,Civil Justice

DOI: $10.7176 /$ JLPG/91-04

Publication date: November $30^{\text {th }} 2019$

\section{Introduction}

Cope with civic disputehas certain characteristic that is path way outside the court and through the court or litigation. Disputant or involved party in civicdispute principally has right to resolve the dispute without any influence or intervention from other parties. Note that in civic procedural law we cannot resolve our interest alone using violence or arbitrary to other person or conduct vigilantism (eigenrichting).

Based on the research data obtained, recently applications of civic lawsuit applying to the District Court are too high. Tis condition of course need means and facility of managing and resolving the problem more professionally, because the presence of principles in civic procedural law reveal as guidance for the judges in examine, adjudicate and decide on a case. (Fence M. Wantu, 2011, Peranan Hakim Dalam Mewujudkan Kepastian Hukum, Keadilan Dan Kemanfaatan di Peradilan Perdata. Disertasi Program Doktor Fakultas Hukum Universitas Gadjah Mada. Yogyakarta. Hlm 476-477). In line with the law No 4 of 2004 that replaced into the law No 48 of 2009 on the Judicial Power, it gives freedom to the judge to do his task and role as the justice upholder, therefore it needs to pay special and deeply attention on any attempts to complete and refine the civic procedural law in the civic court.

This condition need the Indonesian Government to have political will to immediately take concrete actions, to fasten appearance of the New Statute of Civic Procedural Law that able to add and replace oldest regulations, such as HIR and Rbg. In principle, the concepts of HIR and Rbg as the references in civic procedural law till now refer to legacy of Dutch East Indies, and philosophically did not based on the Indonesian soul and way of life.

The regulation in HIR and Rbg has not able to balance the fast development in the law world. For example, HIR and Rbg cannot arrange on the new legal board such as the rice of practice of civic justice using class action lawsuit (group representative) and using of new evidence in electronic system, such as digital signature.

In principally, the writer agree and has no objection to the above opinion, it bring consequence on applying the principle of the civic procedural law itself. Philosophically, reform purposes to review the basic concept and the principle of the civic procedural law. Judicial reform purpose to evaluate the content of norms and positive legal rule applied now. The sociological reform purpose that the new regulations can be accepted by the society.

Based on the fact above, some of the principle in the civic procedural law considered cannot answer the need of civic justice practice today. For example, the principle of civic procedural law require the court conduct using investigation by the panel of judge, recently it depend on the numbers of the judges in the court, especially in the court with B, this procedure cannot be applied when in the same time the court examine 3 or 4 cases. Meanwhile, the number of judges in the court isabout 7 to 8 persons including the Head and Vice Judges.

The legal material covers official documents of any publication of laws. The publication of law involves regulation, governmental regulation, textbooks, legal dictionary, legal journals, and comments on justice decisions. The legal material divide into 3 (three) groups; first, primary legal material. Second is secondary legal material. Third is tertiary legal material. Sunaryati Hartono stating that primary legal material divide into mandatory sources, that is national regulation issued by authority of the legal area, and persuasive primary sources, that is regulation from different province (but related to the same matter) or court's decision from different legal area. The means used to collect the secondary legal material is document study. The analysis method uses qualitative analysis. The qualitative analysis method refers to research procedure to obtain descriptive data. It is in line with the opinion of Maria S.W.Sumardjono, stating that in normative legal research using secondary data, this study basically is descriptive using qualitative analysis.

Based on the research finding, some principles of civic procedural law needed attention, thus in their 
implementation, they would not result in multi interpretation among the legal experts or ordinary people. Some legal principles of the civic procedural law covered:

\section{The principle ofpoint d'interet point d'action.}

Basically, everyone may apply for lawsuit to the court. The principle of point d'interet point d'actionmeans that anyone who has interest may apply for claim of right or lawsuit. The interest means interest based on legal relation between plaintiffanddefendant, and this legal relation directly connect to the defendantconcretely.

This principle has relation to other interest principle in the civic procedural law that isthe principle of actori incumbit probatiomeaning anyone who has a right or reveal an event must prove the truth of the right or the event. Defendantmust prove the relation between himself and the right or interest.

The principle of point d'interet point d'actionis only right not duty. The one with interest (plaintiff) may apply for lawsuit, when his interest isviolated, and anytime he may stop his civic case before the judge makes decision on the case.

\section{The principle of Speedy administration of justice.}

In fact, this principle has not completely applied or in practice, cannot be implemented fully. This principle involve dilemmatic syndrome because it always will face to other system, such as various legal attempts (appeal and cassation) that need a long time, and too firm and formalistic steps of case investigation.

Moreover, to support reconstruction of management system of case fee and push the transparency and accountabley situations especially case finance, in June 2008 the Head of Supreme Court of Republic Indonesia issued SEMA No 4 of 2008 on collecting fee of case. This SEMA decided some important things; to order case financial management using standard of transparency based on legal principle made by each Head of the court; to decide payment mechanism of case fee only via bank and forbid cash payment through the court officer; to order the remaining moneyshould be give back to the related parties, and remaining moneythat not taken back in six months should be sent to state cash as unclaimed money; and order to transfer interest income from consiaytion to the state.

\section{The Principle of Active Judge}

The principle of active judge means that the judge as officer and head of the trial must be active lead the session that it runs well. The judge in this principle is required to decide schedule of trial day and decide the calling, and also order the proofing tools to be prepared. He also must hear the witnesses and expert witnesses for more information. Before the trial begin, the judge has authority to give advice and try to reconcile the two parties, and show legal attempt as the right of the disputing parties.

The action of terminating lawsuit after the defendant giving answer bringsconsequence that the plaintiff has released his right, therefore, he cannot apply the suit anymore. In practice, this termination of lawsuit often happens, with the reason that the lawsuit has been fulfilled by the defendant.

\section{The Principle of Passive Judge(Giving Support).}

This principle always related to idea that justice of any civil case only formal one, thus, disputing resolutiondepends on the disputing parties. The passive judge principle in this civil case must be understood that it's only in deciding the scope of dispute and the right to finish the case by the parties before the judge gives verdict.

The problem appearing in line with this principle of passive judge refer to there is no rule such as regulation arranging clearly on this principle. Yes, the Act 4 verse (2) UU No 48 of 2009 arranged on the court attempt in looking for justice find obstacles, however this act does not talk about the principle of passive judge. Also in the Law of Judge Authority namely the Law No 14 of 1970 jo UU No 39 of 1999 jo UU No 4 of 2004, they did not state clearly this principle.

\section{The Principle of Panel Structure at Least 3 (three) Judges.}

This principle purposes to keep objectivity in examining the case. The research finding conducted by cooperation of several High Institutions in Yogyakarta covering: Anti-Corruption Center (Pukat) of Law Faculty of Gadjah Mada University (UGM), Law Faculty of University of Atma Jaya Yogyakarta (UAJY) and Law Faculty of University of Muhammadiyah Yogyakarta (UMY), who doing Community Service Program of Society Empowering Learning (PPM) with theme "Empowering Society for Justice User" conducted from July-August 2008. This program involved students of university and purposed to review the courts in 15 Regencies/cities in Special Region of Yogyakarta (DIY) and Central Java. The research showed that some violation practices happened in each court such as when violation toward trial exist, the trial keep in process although incomplete judges.

This condition needs to get attention, for the implementation of principle related to panel of judges' 
structure is a must, however the number of judges in the court is inversely proportional to the coming cases. For that reason, in the future, the government must take consideration this condition by adding and pointing new judges. Also, in line with implementation of principle of judge'sstructure, it should keep right by giving warning and sanction to the court that did violation.

\section{The Principle of Open Trial for Public}

This principle become inspection or social control toward the trial process, though not direct control to the trial process with more objective in fair investigation to justice decision for the society. Moreover, this principle purpose to keep the trial process that equal and fair, also protect the right of anyone having casein the court.

This condition of course results in decreasing of social trust toward the court. Thus, claim for transparency of court appear in many places. Transparency becomesinseparable part of accountability. To make that happen, the public should have guaranty to be easier and more independent to accessinformation of trial, includingaccess of court decision.

The trial process is hopefully getting harmony, or at least come to the condition by keeping respect of the legal upholding value. The trial process must be transparent and open toward changes and accept the criticism. The attitude of accepting will result in the responsive trial process. Therefore, the principle of open trial for public in the future must be consistent and conducted. The Drafting Bill of civic procedural law on becoming the Law must be kept Accommodating and arranging clearly on this principle.

\section{Equality Principle.}

In the trial process, the two parties must be treated fairly and given the same opportunity in defend their interests. This principle requires processing equality in the investigation. The judge may not hear only one party, without giving any chances to other party giving his opinion.

The research finding from respondents ideas of the judges, most of them stated that the principle of audi et alteram partem has been conducted based on the law. Generally, each party gets equal opportunity in the trial.

The equality principle of treatment in the court is in line with the justice principle. Meaning that by giving equal treatment to the two parties, plaintiff and defendant, it will create judge's decision having sense of justice to easily realization. Thus, the equal treatment principle in the court must be kept exist and kept in the civic procedural law recently in the process formulation by the government.

\section{The Principle of Justice Conducted: "For the Justice based on the Belief in One and the Only God".} The principle of justice conducted "For the Justice based on the Belief in the One and Only God", have deep meaning toward the judge commitment to always do justice or behave justice in the investigation and giving the decision. The judge in the investigation and decision od case must know and understand the meaning of justice procedurally and substantively, thus, his decision can be responsible to himself, to society and to the Only God. The judge in applying justice based on the Belief in One and the Only God always try maximally to base on the resolution to the God as the control in order to not far from the way of justice and truth. The spirit to always do justice in any case investigation, finally reach the justice decision.

\section{The Principle of Court Ruling Follow with Reasons and Legal Bases(motievering plicht).}

This principle gives duty to the judges in order to include consideration in the decision. The court ruling must include not only reason and decision bases, but also certain acts from the law related to or unwritten legal sources as the basic of to justify.

This principle purpose to the decision must be followed by enough and logic reasons and consideration. The requirement of the existence of reasons and consideration as the decision fundamental will fulfill the claim for justice and objectivity. Event and legal consideration is a unity of the reason for the judge to make his decision.

Based on the research findings in every location, generally, the judge decision in State Court and High court did not include acts as the references or fundamental in resolving the case. The legal analysis on this event considered as legal fact is not found except in the last sentence of the decision stating that "considering the related acts of HIR and Rbg" or the sentence stating: "considering any legal rule and regulation apply". It happens in several decisions of the courts as follow:

Ideally, the judge consideration must have complete and fundamental reason and have objective value as the responsibility to the God, to the disputing parties, society and nation. Thus, the judge in investigating and making legal consideration must be precise and detail in evaluating and analyzingthe legal fact and precise in implementing the act of the law. In the future, the principle of decision followed by reasons and bases, as well as acts of the law must be conducted consistently. The Drafting Bill to becoming the Law of civic procedural law must keep and arrange clearly this principle.

In this discussion, it is not all legal principle of civic procedural law being explained. The writer's reason 
would be most principle that cause problem in its implementation only what explain in the research, whereas other civic procedural law less causing pro and contra in practice.

\section{Conclusion}

In line with research finding, there are some principle of civic procedural law need to get attention, thus in its implementation will not result in multi interpretation among the legal experts or general people who learning them. Several principle of civic procedural law explained above cover: principle of point d'interet point d'action; principle of speedy administration of justice; principle of active judge; the principle of passive judge; principle of judge and panel structure; principle of open trial for public; equality principle; principle of justice conducted for Belief inthe One and the Only God; and the principle of court decision with reasons.

Finally, in this paper the writer recommend a follow: first, it need judge transparency in the level of State Court, High Court and Supreme Court in the trial process to reflect accountability and transparency that increase the better trust from the society. Second, it need to increase and add wider proportion of the Judicial Commission role in watching externally to the judges who conduct against the legal regulation. Third, it need social participation in evaluating the work quality of the judges in the level of State Court, High Court and Supreme Court and report to Supreme Court and Judicial Commission as the external and internal inspector, when find out the judges violate ethic codeandtheregulation.

\section{References}

Halili, Hasrul d.k.k, 2009, Rubuhnya Pengadilan Kami: Rekaman Atas Pelaksanaan KKN Tematik Pemberdayaan Masyarakat Pengguna Pengadilan di DIY Dan Jawa Tengah. PUKAT UGM Open Institute Sociey (OSI). Yogyakarta.

Hartono, Sunaryati, 2006, Penelitian Hukum Di Indonesia Pada Akhir Abad Ke 20, Cetakan Kedua, Alumni Bandung.

Marzuki, Pieter Mahmud, 2006, Penelitian Hukum. Cetakan Kedua Mei. Prenada Media Group. Jakarta.

Mertokusumo, Sudikno2006, Hukum Acara Perdata Indonesia, Edisi Ketujuh Cetakan Pertama Liberty Yogyakarta.

, 2007, Mengenal Hukum Suatu Pengantar, Liberty Yogyakarta.

Muqaddas, Busyro, 2002, Mengkritisi Asas-Asas Hukum Acara perdata, Jurnal Hukum Ius Quia Iustum No 20 Volume 9. Fakultas Hukum Univerias Islam Indonesia Yogyakarta.

Sumardjono, Maria S.W, 2001, Pedoman Pembuatan Usulan Penelitian SebuahPanduan Dasar, Cetakan Ketiga, Gramedia Pustaka Utama Jakarta.

Sutiyoso, Bambang, 2002, Ruang Lingkup Dan Aspek-Aspek Kebijakan Pembaharuan Hukum Acara Perdata Di Indonesia. Jurnal Hukum Ius Quia Iustum No 20 Volume 9. Fakultas Hukum Univerias Islam Indonesia Yogyakarta. 